InOedia $\begin{aligned} & \text { InMedia } \\ & \text { The French Journal of Media Studies }\end{aligned}$

9.1. $\mid 2021$

Film and TV-induced Tourism: Some Contemporary Aspects and Perspectives

\title{
Gazing on Pas-de-Calais: The Romance and Nostalgia of "The Tourist's Gaze" in Pas son genre (Lucas Belvaux, 2014)
}

Jamie Steele

\section{OpenEdition}

\section{Journals}

Electronic version

URL: https://journals.openedition.org/inmedia/2890

DOI: 10.4000/inmedia.2890

ISSN: 2259-4728

Publisher

Center for Research on the English-Speaking World (CREW)

Electronic reference

Jamie Steele, "Gazing on Pas-de-Calais: The Romance and Nostalgia of "The Tourist's Gaze" in Pas son genre (Lucas Belvaux, 2014)", InMedia [Online], 9.1. | 2021, Online since 15 January 2022, connection on 08 February 2022. URL: http://journals.openedition.org/inmedia/2890 ; DOI: https://doi.org/ 10.4000/inmedia.2890

This text was automatically generated on 8 February 2022

(C) InMedia 


\title{
Gazing on Pas-de-Calais: The Romance and Nostalgia of "The Tourist's Gaze" in Pas son genre (Lucas Belvaux, 2014)
}

\author{
Jamie Steele
}

I would like to thank La Cinémathèque Française and BIFI (Bibliothèque du Film) for their help and support in accessing already published film reviews, newspaper articles, and press clippings on Lucas Belvaux's Pas son genre (2014). Thanks also go to the National Library of Scotland for access to some articles, book chapters, and further research on film tourism that helped with the research for this article. The anonymous peer reviewers also provided extremely helpful suggestions along the way.

1 The act of film viewing provides spectators with the opportunity to experience places, locations, and spaces as filtered through the characters and their narratives. This article serves to critically analyse the theoretical interpretations of place, the specificities of location, ${ }^{2}$ and the "tourist gaze" ${ }^{3}$ in the film Pas son genre/ Not my type (Lucas Belvaux, 2014). In so doing, this article asserts that the film moves beyond the local specificities of the city and the region, opening it up to an outsider's and tourist's perspective. The film moves through a series of interplays between the historical architecture of the city and the temporality of the region's beaches, ${ }^{4}$ history and tradition of the region, and the global culture of tourism. It postulates that the "act of gazing" 5 offers a cinematic space that exists only within Pas son genre. Beeton argues that the "act of gazing" transfers the "looked-at" city "to a thing that is being observed in isolation through the world of the viewer, rather than in relation to its own world of existence". ${ }^{6}$ The cinematic space of Nord-Pas-de-Calais is opened up to the "world' of the spectator through the film's narrative, which is constructed through oppositions and "counterpoints", 7 as posited in film reviews of Pas son genre.

In terms of methodology, this article, therefore, aims to consider how both the tourist's and spectator's gaze are framed by the film's locations, i.e. its beaches and cityscapes, 
and camerawork through close reading. In the first chapter to their work on Travel, Tourism and the Moving Image, Beeton uses the notion of "mise-en-scène" to analyse the settings and locations that subject to "glances" and "gazes" in films. ${ }^{8}$ For Urry and Larsen, the "tourist gaze" can be interpreted through a semiotic lens, which, for the purposes of this article, lends itself to textual analysis. ${ }^{9}$ Within Urry and Larsen's "theories" of "the tourist gaze", their eighth typology suggests that "[t]he gaze is constructed through signs"..$^{10}$ This reading is, therefore, specific to the moving image and how the film constructs a space and place through the movements of a traveller or tourist. Beeton also asserts that a gaze is constructed primarily through its relationship with "counterpoints with which it can be compared and contrasted". ${ }^{11}$ Belvaux's Pas son genre provides a logical and coherent case study, since it operates in relation to clear "counterpoints"12, such as the repeated distinctions between Paris and Arras, and Paris and Nord-Pas-de-Calais. The "counterpoints" ${ }^{13}$ of the act of gazing provide nuanced levels of meaning through comparison, i.e. Arras is not Paris since it is differentiated through its landmarks, its people, its traditions and culture. Combining this form of representation, the film is interpreted as readable through the context of the "tourist gaze" 14 and how this informs spectators when constructing a cinematic image of the particular space and place. In fact, the cinematic space of both Arras and the Pas-deCalais region is formed through the rhythm and flow of movement, i.e. how the characters navigate the film's locations, to re-present an image of the area that only exists on screen. Although textual analysis is the dominant methodology for this interpretation of the "tourist gaze" 15 of the film, this argument is further reinforced by a content analysis of film reviews, interviews, and the press pack to better consider the language used to describe the region and city after watching Belvaux's film. ${ }^{16}$ This article engages with screen tourism through the iconic representation of the historical architecture of the city of Arras in opposition to Paris, the temporal and liminal space of the beach as destination and romantic getaway, and the carnival as a "vernacular icon"17 with the nostalgic presentation of its own local customs, traditions, and rituals.

The genre of the film - as a romantic comedy - is significant, since the narrative of falling in love evokes Clément's relationship with Jennifer as well as the location, the place and the region. The film follows Clément, a teacher and intellectual, who - as part of his teaching contract - moves to the Northern French town of Arras. Despite initially being reluctant to leave Paris, his relationship with the local hairdresser Jennifer introduces him to a different side to the town and the region. ${ }^{18}$ In order to experience the French North and the city of Arras, the spectator is aligned with the character of Clément, who arrives in the French North as an outsider, adopting the position of a tourist, to see the way of life as a sociological experiment (as a "counterpoint"19 to Paris).

\section{Screen Tourism: Places in French Cinema}

4 The notion of "screen tourism", as referred in the title of this section on the theoretical approaches to the film, pertains to Beeton's "cinematic tourism" or "film-induced tourism", where "encouraging tourism is not the primary aim". ${ }^{20}$ Urry draws on film in the context of the foundational concept of the "tourist gaze", with film operating as a medium of potential "anticipation" and "fantasy" that "construct[s] and reinforc[es] the gaze". ${ }^{21}$ From this premise, it is the act of looking that is significant, and, for the 
spectator, it is crucial to experience the region and the cities. The theoretical starting point of the "gaze" in this context pertains to the "gaze of the medic" which is "socially organised", ${ }^{22}$ i.e. all that is encountered is gazed upon from a position as an outsider. The locations as viewed on screen frame the cities, the countryside and landscapes as a sites/sights of spectacle. Roberts attempts to "disentangle" some of the key semantics for analysing a film's "landscape", by positing "landscape-as-setting" (via Henri Lefebvre and Martin Lefebvre), the "spatial turn", and the "locative turn". ${ }^{23}$ Beeton posits that there is a "mobilisation" of the gaze, since it relies upon a series of movements, such as "the cultural physical activities of walking and travelling", which resonates with a "virtual gaze" alongside the "moving images". ${ }^{24}$ Williams paraphrases de Certeau as one pathway to broaching this conception of "space" and "place" in relation to the act of walking. ${ }^{25}$ For de Certeau, "walking in the city" has an "enunciative" purpose and represents "a spatial acting-out of the place [...] and it implies relations among differentiated positions". ${ }^{26}$ In essence, "[t]he long poem of walking manipulates spatial organisations", ${ }^{27}$ and this suggests that, in the case of film, the character connects spaces and locations, bringing them together through the act of walking. There is a linking effect that is generated by the characters as they move through space. In the context of film, how the characters move around and through the city, in this case, is "transformative", ${ }^{28}$ since they guide the spectator through the "space". This is particularly productive for the character of Clément in Pas son genre, as he strolls through Arras, showing the space of the small city as easily digestible snippets. Short clips of the film on video sharing sites like Youtube, for example, are useful for highlighting how spaces and locations in the film can be watched, shared, and experienced beyond the film's narrative..$^{29}$ They offer easily digestible iconographic images of the city and the region. The character represents the figure of the tourist, directing the 'tourist gaze' ${ }^{30}$ through Arras and the Pas-de-Calais region. As such, two key themes emerge: the notion of romance and the act of falling in love with a local and the city, and an outsider's nostalgic perspective of past traditions.

5 The acknowledgement of "signs" and a semiotic understanding of place and space also overlap with "the production of "images" that have an "iconic" significance. ${ }^{31}$ Riley, Baker and Van Doren suggest that, in the context of "movie-induced tourism", "icons, abstract or tangible, become the focal point for visitation and the associated location is tangible evidence of the icon". ${ }^{32}$ In this context, the place and landmarks have the potential to resonate with spectators, and it may encourage them to visit the exact locations. However, when discussing the "icon" and the film as text, Urry and Larsen argue that there are three types of "icons" - "global icons (the Eiffel Tower), iconic types (the global beach) and vernacular icons (Balinese dances)" - when it comes to the overarching concept of the "tourist gaze" and the "circulation of these images" in popular media. ${ }^{33}$ This understanding of signs, symbols and icons are significant to the image of Arras and the Nord-Pas-de-Calais region in Pas son genre. It engages with all three forms of icons that are recognisable to the spectator, i.e. the belfry, the beaches of Northern France, and the local carnivals. This approach coheres with the primary case study of this article, Pas son genre, which operates in symbolic terms to simplify the interactions between Paris and Arras as "counterpoints". ${ }^{34}$

6 The depiction of Arras in Belvaux's Pas son genre is one that is not tempted to draw attention to the 'beauty' or uniqueness of the city in comparison to TV programmes, such as the series 'Favourite French Monument' on France 2, which have sought to 
change the image of the city to a status of destination. The diegetic place created within Pas son genre is filtered through a nuancing of stigmatising perceptions of the city and the region, for example Clément's initial response to the city and his preconceptions of Arras and Nord-Pas-de-Calais, and the narrative of falling in love.

\section{Directing the "Touristic Gaze": Clément as guide and traveller}

7 Clément, the teacher who journeys from Paris to Arras, structures this cinematic experience through space and place. The character carries the focus through the city, counterbalanced by his exploration (with his new-found love, local hairdresser Jennifer) around the local area, its beaches and traditions. Roberts primarily adopts a textual approach - a "locative" and "spatial turn" - to understanding "screen tourism", focusing on close reading of the landscape in a selection of British noir TV series. ${ }^{35}$ Adapting this approach to the representation of the diegetic spaces of Arras in the romantic comedy Pas son genre, Clément is placed in the position of an outsider and a tourist within the film's narrative. As Belvaux observes in the film's press pack, "He's [Clément] there like an outside spectator to it all" ${ }^{36}$

Clément adopts the position of the tourist or traveller through his decision to live in a hotel in the city centre of the town. This is evocative of the main characters in films such as Lost in Translation (Sofia Coppola, 2003) and In Bruges (Martin McDonagh, 2008). His status - as both a tourist and outsider - is consolidated by his temporary placement in Arras. ${ }^{37}$ Clément is required as part of his contract as a teacher to be placed in a location that is selected by the national authorities. ${ }^{38}$ As a citizen of Paris, it is Clément's preference to remain in the capital city, yet the selection is out of his control and, against his wishes, the national authorities place him in Arras for an academic year. In France, the act of commuting from Paris to other regions is common for teachers, and it is possible to contend that clément adheres to the general perception of a normal lifestyle for a civil servant teacher. Viewing from outside the context of the French education system, Clément's lifestyle also resonates with the postmodern traveller, the businessman and commuter. ${ }^{39}$ Clément stays at the Hôtel de l'Univers in Arras, as evidenced by the film's final credits. There is no commitment beyond a temporary stay, and this resonates with the tourist's travel and journey to the city as well as the spectator's 'stay' during the film. The karaoke scenes - which are used by Belvaux to narrate the love story and Jennifer's feelings regarding her relationship with Clément ${ }^{40}$ - recall Lost in Translation and its engagement with liminality. The karaoke sequences and hotel rooms seen in the film become a sign of "contemporary global culture ${ }^{\prime 41}$ alongside the visit to the beach as shorthand references to forms of holidaying and leisure. The use of popular American music, such as The Supremes' You Can't Hurry Love and Gloria Gaynor's I will survive sung in English by the French and Belgian actresses, ${ }^{42}$ further indicates a stretching out to the global. The use of Gaynor's I will survive as a karaoke song is more than just a familiar and recognisable American song in France, since it also has a national and cultural resonance. During the FIFA World Cup in 1998 in France (France '98), the song became the unofficial national anthem for the French soccer team. It started during the tournament as the squad's "locker room anthem" ("hymne de vestiaires") ${ }^{43}$ and served as the team's "own theme tune" ${ }^{\prime 4}$ as they won the World Cup as the host nation. Gaynor's song, as sung by 
Jennifer, resonates with global audiences through disco music, through the song being an important anthem for LGBTQIA+ audiences ${ }^{45}$ and for its national resonance for a sense of togetherness, belonging, and celebration in France in the late 1990s. As a result, the story - through its use of music - is articulated and narrated in a manner that is universal, accessible and easily decipherable to a mass audience.

9 As a survey of film criticism of the film outlines, there is a clear line drawn between Arras and Paris, as symbolic of cultural and social difference and specificity. ${ }^{46}$ The primary mode of connection between the two locations - or 'sites' - refers to the means of journeying to-and-from Arras from Paris, the French centre towards the provinces or regions. Pas son genre shows the act of journeying (or travelling) on the TGV (Train à Grande Vitesse/ High Speed) as the link between the two cities. The trains and railway resonate with film and cinema through the references to mobility. Beeton further suggests that, "the transport developments made places more accessible, the popular media made them more desirable". ${ }^{47}$ It is precisely this notion of 'accessibility' that highlights the ease of reach to get to Arras and to join the Northern city with the centre, Paris. The trains and the railway articulate movement and mobility, transporting the protagonist, the traveller and the tourist to the destination. As Bazin et al. propose, the TGV service routes for "Small and Medium size" cities "is perceived as an opportunity to improve the image, to increase its attractiveness and, in certain instances, as a resource that allows for the development of tourist activity". ${ }^{48}$ However, the scholars posit that the "TGV effect" is negligible statistically for Arras, and is, instead, an "image effect" generated by "Arras Tourist board and it is, therefore, indirect" and a "facilitator" of tourism..$^{49}$

Pas son genre presents this 'image' of the recommended use of the TGV to visit the city of Arras. It coheres with the general perception offered through tourism discourse. The TGV has a cultural resonance and significance in terms of representing the journey from Paris to Arras. ${ }^{50}$ It represents speed and the compressing of a distance between Paris and France's Northern cities. ${ }^{51}$ This form of travel is also expensive, drawing attention to the class distinctions present within the film, as Clément shows his middleclass privilege through his act of commuting. With the TGV, Arras is easily reachable within a relatively short period of time (approximately $50 \mathrm{~min}$ ), showcasing the possibilities of high-speed travel in an era of postmodernity. The sequence unrolls for thirty-seconds, positing a short journey time between Paris and Arras. In the background, the TGV rapidly passes through the French countryside, which emphasises the move towards the North and the regions away from the centre of Paris. ${ }^{52} \mathrm{It}$, therefore, suggests that the town could operate as a location for a short-stay, to frequent the city's centre and its main landmarks, such as the main squares and the belfry, as well as Pas-de-Calais' coastline and events, such as the local carnivals. What is most revealing is that Arras is geographically close to Paris, but culturally and socially distinct from the Metropole notion of French identity. Paris pertains to a "snobbish" 53 idea of Frenchness, of bourgeois intellectualism (resonating with Hollywood's feature films and their 'exotic vision' of Paris in Funny Face [Stanley Donen, 1957]), whereas Nord-Pas-de-Calais is presented as down-to-earth, populated by individuals who are woven into the fabric of the local community. It is this dichotomy that lies beneath the relationship between Parisian Clément and the local Arrageoise Jennifer, and the ultimate failure of their romance. 
11 When Clément first arrives in the Northern French city, his colleague Hélène PasquierLegrand introduces him to the city centre and its main squares. Although not celebrating the city and offering a degree of pride, Hélène informs Clément - and by association the spectator - about Arras' heritage. She notes that the belfry is "on the [UNESCO] World Heritage list". The spectator is, therefore, immediately introduced to the city's history. The belfry is also concomitant with the region, and thus functions as a means of signalling its difference from the centre of Paris as regional and distinct. As the bells ring across the city centre - heard from one of the other main squares - the camera tilts down the belfry from its spire, highlighting its 'iconic' status in the city. The bells operate as a motif throughout the film, reverberating through the space between the main squares, Jennifer's salon and Clément's hotel room. The immediate interaction of Clément with the city as he strolls through the centre with Hélène presents the city as readable. They create a space, organised from this point, to emphasise their close proximity in the centre. The city centre is simplified into a series of codes - of squares, cafés and "icons" 54 - to firmly locate the spectator, whilst, at the same time, offering up the city's aesthetic qualities for the tourist to gaze upon. The wandering is also evocative of the contextual analyses of tourism in Nord-Pas-de-Calais and Arras in particular, which pointed to Parisian tourists being primarily fascinated by its city centre and spending the majority of their time in this area. ${ }^{55}$ Mérigeau alludes to the identification of the character and the tourist at this point, by suggesting that " $[\mathrm{t}]$ he spectator feels almost comforted having had to stay in the position of a voyeur, waiting for the cobblestones of the North to give way beneath the feet of the loved-up pretty girl". ${ }^{56}$ It is only when Émilie Dequenne's character Jennifer is introduced that the touristic and 'voyeuristic' gaze on the city centre is lifted. Belvaux also uses the "icon" 57 of the city as a bookending device, since it appears at the start of Clément's stay in Arras and lurks in the background of Belvaux's final shot in the city centre. In this scene, Clément paces in circular motion in the main square. The camera tracks Clément's motion in full 360-degrees, capturing the Flemish-style architecture and the belfry. In so doing, the backdrop of the main square operates as a theatrical setting for the film's dénouement: the tragedy of the breakup of their relationship. ${ }^{58}$ The glimpses provide momentary references to key landmarks and public spaces that are given meaning through the rhythm of Clement strolling through the city. It is precisely this strolling through the city, particularly at night, which "transforms" 59 the gaze upon the city through Clément's acts of travelling. In the city centre, Clément takes the spectator through the space of Arras, drawing attention to its historic architecture and its proximity to Paris. As Clément's relationship with Jennifer - the local hairdresser - evolves, his understanding of the local area expands to its beaches (Urry and Larsen's "global icons") ${ }^{60}$ and the region's local traditions, such as the carnival. At this point, there is a shift in narrative agency from Clément to Jennifer. Jennifer assumes the role of introducing the spectator to new places through Clément, since it is her who shows Clément the local cinema, the nightclub and karaoke bar, and her apartment. This is one of the main differences between the novel and the film, since Belvaux's film permits alternating perspectives that move between Clément to Jennifer. In the press pack, Belvaux contends that, "I decided to readjust the points of view in order to observe the characters from the same distance and to treat them in the same way". ${ }^{61}$ Through this alternating perspective, the film offers the spectator a new pathway to see and experience the city in a more authentic way. 


\section{Pas-de-Calais' Beaches: The Temporal Experience of Tourism}

12 Outside the city centre of Arras and the carnival at Cassel (although the location is not noted in the film), the characters move seamlessly between the coast and Arras city centre, with no framing of the act of journeying. The two trips to the beach are places of escape for Jennifer. The beaches are similarly unnamed in the film's dialogue, positing the proximity of Arras to the coastline when adopting Wollen's "mental map"62 analogy. Belvaux adopts a widescreen, "anamorphic Cinemascope" aesthetic throughout the film. ${ }^{63}$ This neatly captures the wide horizons and space of Pas-deCalais' beaches. The beach is unnamed in the film, and the end credits include two coastal resorts in Berck-sur-Mer and Touquet-Paris-Plage. In these two sequences, a reverberation of technique is adopted, with the use of travelling shots that, when pieced together provide a framing of the promenade and coastline at the resort. In essence, the pattern in the shot types creates a "logical spatial relationship" ${ }^{64}$ between the two beach landscapes.

The contrast between the historical architecture of the city of Arras and town of Cassel and the space of the beach is particularly instructive, since it highlights the transitory nature of the tourist's experience in the region. It ticks the semantic boxes of the tourist's everyday experience, i.e. seeing and gazing at local traditions, histories, events and architecture, with the less fixed space of the beach, marked by a lifting of temporality. It is a shifting space of romantic interpretations of a loving and emerging relationship. Its lack of fixity is coherent with the global cultures of travelling, where 'exotic' places are marked by their non-descript beaches, laden with golden sand and clear seas. In essence, the scenes participate in the tourist's interpretation of the experience of romance and holidaying, presenting an image of the region that is fluid and where one can escape the constraints of temporality that exist within the neoliberal and capitalist system of work, coded by time.

In the first sequence on the beach, Clément and Jennifer are sitting, wearing their winter coats and scarves to fight against the strong breeze along the coastline, as the camera pans from right-to-left, on the left side of the two characters. The sequence opens with the coastline, with the twentieth century post-WWII buildings lining the seafront, before being placed alongside the two characters as they gaze out to sea. The slow movement of the camera constantly re-frames the characters in dialogue, once again, turning back towards the coastline. Discussing this sequence, Belvaux argues that,

[t]he scene on the beach begins with a long traveling shot where they do not say anything to each other and then, both of them get involved in a discussion at that moment in space and time. It is important to film them where they are, and convey the passing of time visually. ${ }^{65}$

The long take - lasting 1 minute 16 seconds - shows the vast space of the beach and its coastline. It captures the sense of a wide, open space, as well as being a place of escape from the city where they can be alone and reflect on their relationship. The second sequence at the coastline - of Jennifer alone contemplating her relationship with Clément - arcs around her body from left-to-right along the right-hand side of the character. As a result, the camera concludes the sequence with a slow, oscillating pan. Jennifer gazes away from the camera, out to sea, as the spectator gazes in the opposite 
direction, back to the coastline and the promenade. The arching movement of the camera establishes a pattern between the two sequences to form a cinematic space of artificial wholeness. The rhythm creates an imagined conception of the Northern coastline and posits that the location is the same. The final movement of the pan in the circle reveals crucial information lurking in the background of the frame. Gazing back at the coastline, buildings are slowly revealed through the motion, the distinctive hospital building with a clock tower, Berck-sur-Mer's Hôpital Cazin-Perrochaud. The "indexing" ${ }^{66}$ of Berck-sur-Mer on Locations Film France includes an image that strongly resonates with the final moment of Belvaux's Cinemascope, deep-focus frame. The website claims that:

Despite the destruction of the waterfront during the war, Berck offers a variety of houses of the nineteenth and early twentieth exceptional by the diversity of styles and a large beach, a wide variety of activities and places of recreation, hotels and restaurants that attract touristes $[\mathrm{sic}] .{ }^{67}$

The panning motion creates the illusion of a wide-open beach through the pattern of the circling camera. The pan, arching around Jennifer as she is sitting alone on the beach of Berck-sur-Mer, signposts the "indexed" 68 image of the coastline and the town, whilst still acknowledging the 'large beach' through the deep-space. The beach clearly stretches into the distance. As these sequences on the local beaches articulate, the "global icon" 69 of the beach is laced with connotations of romance and holidaying. It lifts the temporality of the work patterns of the city to offer a space where Jennifer and Clément can fall in love, and, latterly, contemplate their relationship. The beaches are specific to local audiences (i.e. through the recognisable architecture in this distance) and simultaneously global to international audiences. However, the film serves to further localise these areas to global audiences through its engagement with local customs and traditions, such as the carnival, which clearly provides a "vernacular"70 to the spectators.

\section{Carnivals as "Vernacular Icons"71}

17 Through the act of travelling between Paris and Arras, Pas son genre articulates a dynamic that differentiates the way of life and experiences of living in Paris with Arras as a representative of the French regions. The mise-en-scène offers a unique perspective of cultural particularities, which communicate a sense of nostalgia for the local customs and traditions, in opposition to the presentation of upper middle-class, non-descript areas of Paris.

Returning to Urry's foundational concept of the "tourist gaze", Urry and Larsen offer the notion of a "collective tourist gaze", which "involves conviviality. Other people also viewing the site are necessary to give liveliness or a sense of carnival or movement. Large numbers of people suggest that this is the place to be". ${ }^{72}$ The film captures the carnival in its local context, providing an authentic representation of the region to an outsider or traveller. Beyond a textual analysis of the location of Cassel and its semiotic presence in Pas son genre, the location is also present on the screen agencies' websites, namely Film France in this case. In terms of theoretical approaches to "location mapping", Roberts observes that, "the actual landscape [is] digitally captured in indexes and databases of location sites held by [...] mediating bodies" ${ }^{73}$ The Film France location server includes 21 images of the small town in French Flanders, evidencing 
that it is "considered as one of the most beautiful villages in France" with its small "cobbled" streets. ${ }^{74}$ However, the server does not include the small-town's carnival one of its regional and local selling points - and, instead, it makes only slight reference to its "exceptional historic heritage" and "particular atmosphere" in the context of "traditional regional architecture". ${ }^{75}$

The carnival at Cassel functions as an example of the aforementioned "vernacular icon" ${ }^{76}$ since the event in Pas son genre operates as an expression of cultural specificity. In essence, the event of the carnival and the location of Cassel are presented to outsiders as a site of 'authentic' representations of local traditions in Northern France. Aligning with Clément, the spectator arrives fresh at the event, experiencing it as an 'icon' of local traditions. In L'Humanité, Widemann proposes that the carnival "imprints the region's proud identity" on the film. ${ }^{77}$ Belvaux, in the film's press pack, asserts that,

[c]oming from Belgium, I feel at home there [Arras]. The carnivals, the brass bands, the beer, the fries, the friendliness, these are cultural codes I'm familiar with. Clément doesn't come from this area. He thinks it is a punishment to live in this city, far from the world, from his world, although it is only an hour and a half from Paris. $^{78}$

As a result, the carnival provides the film with a clear location in the French North. The event captures the specificity of the French Flanders region and of its spirit and atmosphere as different to the metropolitan centre in Paris.

In Le Canard Enchainé, Fontaine argues that Belvaux's film still operates within the context of a "snobby" and "Parisian" view of the Northern regions through its depiction of Arras and Paris as diametrically opposed locations in France. ${ }^{79}$ The framing of the region from a Parisian perspective is quite productive, since it neatly sums up the interactions between Clément and Jennifer and how Clément engages with the local and regional contexts. Clément's interpretation of the way of life in Arras is indifferent and over-valorises Parisian life and culture. This is indicated by an insider/ local outsider/ tourist dynamic within the film. During the carnival, Clément's schoolteacher colleague (Hélène) introduces him to her husband (both from the neighbouring city of Lille) when they encounter one another in Cassel. Hélène, her husband and Clément articulate a 'snobbish' perspective and interpretation of the local carnival. As Clément does not introduce Jennifer to his colleagues, she is hurt by his behaviour, and then decides to end the relationship. In essence, Clément, Hélène and her husband are engaging with local culture and customs as outsiders and as tourists, and they all consider themselves different from the locals who are actively participating in the event. There is a hierarchy at play in which those who are outsiders or travellers to the region adopt a position of supposed "superiority" to the "vernacular" ${ }^{80}$ events playing out in front of them. As Sotinel writes in Le Monde, Pas son genre "would be a romantic comedy [...] if Lucas Belvaux agreed to declare a truce in the class war". ${ }^{81}$ Class stratifications play a role in the establishment of this hierarchy, with the bourgeois, middle-class characters, such as Clément, afforded mobility and movement, which is, as a result, aligned with the figure of the tourist. The local, working-class characters, such as Jennifer, serve as a point of intrigue and are "looked at" through the "tourist gaze". ${ }^{82}$ This power dynamic of subject/ tourist and object/ local is viewed through the lens of class distinctions. The tourist is not participating in the event - much like the spectator as they "gaze" - and this forms a power dynamic between the tourist and the local. For the local, Jennifer, the event serves as an opportunity to showcase the region's identity, difference, and individuality, but for clément, Hélène and her husband, it is an 
experience of the region's "vernacular" 83 and an anthropological experience articulated through power dynamics of the "gaze". The outsiders and travellers hold the local customs, traditions, events and even people (such as Jennifer in this case) at a distance. As a result, the cumulative effect is a pejorative treatment of the carnival and event, reduced to a touristic experience for the outsiders, who are present only to "gaze" at the local customs as "vernacular icons". ${ }^{84}$

In Belgium and France, "traditional processions" serve to represent "intangible cultural heritage" as recognised by UNESCO. ${ }^{85}$ As Fournier further outlines, the "effigies" of "Processional Giants and Dragons" are a historic and 'still practiced' tradition for many French and Belgian towns, forming a key part of their local 'identity'. ${ }^{86}$ Baycroft argues that these "festivals of the giants constitute one element of regional culture which has flourished even more strongly in the twentieth century". ${ }^{87}$ Cassel's carnival is localised by "the giant Reuze and his wife [Reuze-Papa and ReuzeMaman] who tower over the procession". ${ }^{88}$ Gueusquin suggests that it is even possible to narrow down the time of year that the ritual occurs, since the giants appear "twice a year (the man at Mardi Gras, and the couple on the afternoon of Easter Monday), their ritual walks celebrate and periodically consolidate a space of belonging and celebration for the [local] population". ${ }^{99}$ The carnival represents a moment of "spectacle" in which "everyone participates". ${ }^{90}$ What is more, for Cassel in particular, the carnival and procession "ha[ve] become a significant part of the local touristic development program[me] and a new museum has been created". ${ }^{11}$ The carnival, as exhibited in Pas son genre, articulates a centre and margin dynamic, between Paris and the regions, and this lies at the heart of the film.

The carnival sequence opens with the figure of the giant, Reuze-Papa, as his effigy is held aloft by the small-town's inhabitants. References to the region - French Flanders are articulated through the numerous flags waved as part of the celebrations. The giants of Reuze-Papa and his wife travel through the diegetic space of Cassel, amongst a crowd of people wearing outlandish and colourful costumes as a form of local and regional expression, heritage and pride. The images of the streets also strongly resonate with the stock location images of the village centre, particularly in terms of shot composition and the mise-en-scène of the traditional buildings and Flemish architecture included in the frame. Like the city centre of Arras, the Flemish architecture of Cassel operates as an invocation of local traditions and stories. Jennifer represents the locals in the crowd, with her orange hat (with sunflower attached), scarf and eye-shadow, as well as her purple, red and blue badges adorning her black coat. Her image is combined with the local surroundings and the carnival to mark her as a living artefact of the region. Clément, in the role of the outsider and tourist in this context, whilst walking amongst the crowd, stands out due to his difference. He has a muted costume that fits neatly with his stereotyping of the Parisian philosopher, with only a small flourish of a furry orange handkerchief placed in his coat pocket. Whereas Jennifer's colourful costume is an evocation of her pride for her regional identity, the "tourist gaze", ${ }^{2}$ as indicated by Clément, is one of intrigue and curiosity, where active participation is not fully required. Jennifer's costume indicates that she is an active participant in the local custom and the carnival, and this draws her into the crowd. Siding with Clément, the spectator gazes into the event as an onlooker. ${ }^{93}$

The cinematography combines with Clément's suit to heighten his sense of alienation, whilst simultaneously evoking the breakdown in the couple's relationship. The slow- 
motion cinematography captures Clément's sense of being out of place, as well as proving revelatory for Jennifer as she recognises the breakdown of this relationship. The relationship between the two characters either representing Paris or the provinces is not long-term. It is nothing more than an articulation of a holiday romance, evocative of rom-com scenarios in 'exotic' places, such as Roman Holiday (William Wyler, 1953). In Télérama, Strauss contends that the carnival in the provincial town represents 'a claustrophobic spiral' ${ }^{94}$ The film critic considers both Jennifer and Clément as "prisoners as a result of their job, their social status, or even their taste". ${ }^{95}$ In fact, the carnival charges Jennifer with a certain power and agency to move on with her life with her son, rather than continue on this path with Clément. Rather than operating as a form of "prison" - as posited in Le figaroscope ${ }^{96}$ - for Jennifer, her decision to leave Arras (and end the relationship with Clément) frees her from issues of class, social status and her relationship, proffering mobility through the final image of Jennifer's empty apartment. This ending contrasts with the previously consolidated paradigm of "immobile bodies (normally female)" with the "tourist gaze" codified as male.97 Clément is closed down in a "prison" (adopting Simon's terms), ${ }^{98}$ and, at this moment, Jennifer is liberated. She transcends the restrictions of class, as suggested in the film's reviews, in the working-class city.

This article has argued that Pas son genre coheres with the theoretical interpretations of screen tourism and the traveller's experience of space and place through the character of Clément (from Paris) and how he experiences the local culture, traditions, events, carnivals and historic architecture. Referring back to de Certeau's foundational work, Pas son genre offers a "synecdochal" 99 articulation of the cinematic space of Nord-Pasde-Calais, structured through the references to icons and signs of the region. These become recognisable to audiences, building up a system of images that reach local, national and transnational audiences. The historical architecture of the city centre (its belfry and its squares) and the carnival at Cassel, and the temporality of the beach showcase the plurality of the sites and sights in Nord-Pas-de-Calais. They are all charged with different significations, and they are each 'iconic' in their own contexts. The relationship between Clément and Jennifer nuances the three spaces, providing layers of meaning through their own backgrounds and romance. The "tourist gaze" 100 is one that is laced with the 'romantic' (the narrative of falling in love) and the 'nostalgic' (harking back to local traditions) that is counterbalanced by the capital, Paris.

\section{BIBLIOGRAPHY}

Agat Films \& Cie and Aretmis Productions. "Not My Type Dossier de Presse", Unifrance.org. Accessed on January 8, 2019. https://www.unifrance.org/film/35692/pas-son-genre

Alion, Yves, and René Marx. “À l'occasion de la sortie de Pas son genre: Entretien avec Lucas Belvaux", Avant-Scène Cinema, no. 615 (2014): 124-129.

Augé, Marc. Non-Places : Introduction to an anthropology of supermodernity, London ; New York : Verso, 1995. 
Baycroft, Timothy. Culture, Identity and Nationalism: French Flanders in the Nineteenth and Twentieth Centuries, London; Rochester, New York: Royal Historical Society, 2004.

Bazin, Sylvie, Chrisophe Beckerick, and Marie Delaplace. "Desserte TGV et villes petites et moyennes. Une illustration par le cas du tourisme à Arras, Auray, Charleville-Mézières et Saverne", Les Cahiers scientifiques du transport, AFITL, no. 63 (2013) : 33-61. <hal-01184947>. Beeton, Sue. Travel, Tourism and the Moving Image, Bristol; Buffalo; Toronto: Channel View Publications, 2015.

Bergfelder, Tim, Harris, Sue., and Sarah Street. Film Architecture and the Transnational Imagination: Set Design in 1930s European Cinema, Amsterdam: Amsterdam University Press, 2007.

Blay, Jean-Pierre. “«Qu'est-ce qu'une nation »... Qui joue au football?”, Cahiers des Amériques latines [Online], 39 | 2002, Online since 06 August 2017, Accessed on September, 7 2021. URL: http://journals.openedition.org/cal/6668; DOI: https://doi.org/10.4000/cal.6668 .

Dauncey, Hugh, and Geoff Hare. “"33 jours de fête”: A diary of France 98', Culture, Sport Society, 1, no. 2 (1998): 184-204. < DOI: 10.1080/14610989808721822>.

de Certeau, Michel. "Walking in the City", In The Practice of Everyday Life, Translated by Steven Rendall, 91-110. (Berkley: University of California Press), 1984.

Faroudja, Yves. "Television system with variable aspect picture ratio", United States Patent. Accessed on March 30, 2019. https://patentimages.storage.googleapis.com/ 32/01/00/80a06c2604957c/US4951149.pdf..

Fontaine, David. "Pas Son Genre: Arrageois de vivre", Le Canard Enchaîné, April 302014.

Fournier, Laurent-Sébastien. "Intangible Cultural Heritage in France: From State Culture to Local Development", In Heritage Regimes and the State, edited by Regina F. Bendix, Aditya Eggert, and Arnika Peselmann, Göttingen Studies in Cultural Property, Vol. 6, 327-340. Göttingen: Universitätverlag Göttingen, 2013.

Gallot, Clémentine, “Pas son Genre”, Cahiers du Cinéma, No. 699, April 2014, p. 58.

Goubert, Camille, Youtube, Accessed August 31, 2021, https://www.youtube.com/channel/ UCg6VDJ3spV8gkVZ_LcEM1fw/.

Gueusquin, Marie-France. "La ville et l'effigie: Emblématique et identités urbaines dans le Nord de la France au XXe siècle”, Revue du Nord, 69, no. 274 (1987): 659-677.

Handyside, Fiona. The Cinema at the Shore: the Beach in French Film, Berne: Peter Lang, 2014.

Harrod, Mary. From France With Love: Gender and Identity in French Romantic Comedies, London: Bloomsbury, 2015.

Hopewell, John. "The Idea That Cinema is Also Art Protects Us a Bit", Variety, January 10, 2014. Accessed December 8, 2021. https://variety.com/2014/film/global/lucas-belvaux-the-idea-thatcinema-is-also-art-not-just-an-industry-protects-us-a-bit-1201048558/.

Hubbs, Nadine. “'I will survive”: Musical Mappings of Queer Social Space in a Disco Anthem', Popular Music, 26, no. 2 (May 2007): 231-244.

Kaganski, Serge. "Pas son genre de Lucas Belvaux", Les Inrockuptibles, April 30, 2014. Accessed December 8, 2021. https://www.lesinrocks.com/cinema/pas-genre-lucasbelvaux-109948-30-04-2014/.

Lapostolle, Guy and Thierry Chevaillier. 2011. "Teacher Training in France in the early 2010s", Journal of Education for Teaching, 37, no.4, Taylor \& Francis: Routledge, 451-459. 
Locations France Film. "Presentation Sheet Berck-sur-Mer", Francefilm.net, Accessed March 28, 2019, https://locations.filmfrance.net/location/presentation-sheet-berck-sur-mer.

Locations France Film. “Village de Cassel”, Francefilm.net, Accessed March 28, 2019, https:// locations.filmfrance.net/fr/location/ville-de-cassel.

Lorrain, François-Guillame. « Dequenne, c'est notre genre ! », Le Point, May 01, 2014.

Mérigeau, Pascal. "L'amant de la coiffeuse", Le Nouvel Observateur, May 1, 2014. Accessed December 8, 2021. https://www.nouvelobs.com/magazine/20140501.OBS5738/l-amant-de-lacoiffeuse.html.

Mintzler, Jordan. "Not my Type (Pas son Genre): Film Review”, The Hollywood Reporter, April 23, 2014. Accessed December 8, 2021. https://www.hollywoodreporter.com/review/not-my-typepas-son-698267.

Riley, Roger, Dwayne Barker, and Carlton S. Van Doren. "Movie-Induced Tourism", Annals of Tourism Research, 25, no. 4 (1998): 919-935.

Roberts, Les. "Projecting Place: Location Mapping, Consumption, and Cinematographic Tourism". In The City and the Moving Image: Urban Projections, edited by Richard Koeck and Les Roberts, 183-204. London: Palgrave, 2010.

Roberts, Les. "Landscapes in the Frame: Exploring the Hinterlands of the British Procedural Drama”, New Review of Film \& Television Studies, 14, no. 3 (2016): 364-385.

Simon, Nathalie. “Émilie Dequenne, Féminin Plurielle”, Le Figaroscope, April, 302014.

Sotinel, Thomas. « " Pas son genre » : L'amour est un champ de bataille », Le Monde, April 30, 2014. Accessed December 8, 2021. https://www.lemonde.fr/culture/article/2014/04/29/pas-songenre-1-amour-est-un-champ-de-bataille_4408803_3246.html.

Steele, Jamie. Francophone Belgian Cinema, Edinburgh: Edinburgh University Press, 2019.

Steele, Jamie. « Political Discourse and Rhetoric : Challenging twenty-first century populism in Chez Nous/ This is Our Land ", In The Routledge Companion to European Cinema, edited by Gabor Gergely and Susan Hayward, 437-449. London : Routledge, 2021.

Strauss, Frédéric. "Pas Son Genre, Lucas Belvaux", Télérama, April 30, 2014.

Thabourey, Vincent. « Pas son Genre », Positif, 639, May, 2014, p. 42.

Urry, John. The tourist gaze: leisure and travel in contemporary societies, London: Sage Publications, 1990.

Urry, John, and Larsen, Jonas. The tourist gaze 3.0, London: Sage Publications, 2011.

Vlaeminckx, Jean-Michel. 2014. "Pas son genre de Lucas Belvaux", Cinergie, (1 May). Accessed February 7, 2019. https://www.cinergie.be/actualites/pas-son-genre-lucas-belvaux.

Widemann, Dominique. “Un film d'amour comme on parle d'une lettre d'amour”, L'Humanité, April 30, 2014. Accessed December 8, 2021. https://www.humanite.fr/un-film-damour-commeparle-dune-lettre-damour-523814.

Williams, James. Space and Being in Contemporary French Cinema, Manchester: Manchester University Press, 2013.

Bienvenue chez les Ch'tis/ Welcome to the Sticks, directed by Dany Boon. France: Pathé Renn Productions/ Hirsh/ Les Productions du Chicon, 2008.

Funny Face, directed by Stanley Donen. United States of America: Paramount Pictures, 1957. 
In Bruges, directed by Martin McDonagh. United Kingdom/ United States of America: Focus Features/ FilmFour/ Blueprint Pictures, 2008.

Lost in Translation, directed by Sofia Coppola. United States of America/ Japan: Focus Features/ Elemental Films/ American Zoetrope/ Tohokushinsha Film Corporation, 2003.

Ma loute/ Slack Bay, directed by Bruno Dumont. France/ Germany/Belgium: 3B Productions/ Twenty Twenty Vision Filmproduktion GmbH/ Pallas Film, 2016.

Pas son genre/ Not my type, directed by Lucas Belvaux. France/ Belgium: Agat \& Cie, 2014.

P'tit Quinquin/Li'l Quinquin, directed by Bruno Dumont. France: 3B Productions/ Arte/ Pictanovo Nord-Pas-de-Calais, 2014.

Quand la mer monte/ When the sea rises, directed by Yolande Moreau and Gilles Porte. Belgium/ France: Ognon Films/ Stromboli Films/ Radio Télévision Belge Francophone, 2004.

Roman Holiday, directed by William Wyler. United States of America/ Paramount Pictures, 1953.

\section{NOTES}

1. John Urry, The tourist gaze: leisure and travel in contemporary societies (London: Sage Publications, 1990).

2. Sue Beeton, Travel, Tourism and the Moving Image (Bristol; Buffalo; Toronto: Channel View Publications, 2015), 6-36; and John Urry and Jonas Larsen, The tourist gaze 3.0 (London: Sage Publications, 2011), 1-30. Roberts also offers the method of "location mapping" and "movie mapping" in film tourism to better understand the "poetics of place". See: Les Roberts, "Projecting Place: Location Mapping, Consumption, and Cinematographic Tourism". In The City and the Moving Image: Urban Projections, edited by Richard Koeck and Les Roberts (London: Palgrave, 2010).

3. Urry and Larsen, The tourist gaze 3.0, 1-30.

4. This is an observation that Catherine O'Rawe (2021) posited during a general discussion for the Bristol Screen Research seminar in the context of films set in port cities, and the interplay between historical architecture and beaches. This idea holds true in the case of film tourism and the historical architecture of Arras, which is counterbalanced by the liminal and temporal spaces of the beach. Also, see Handyside for an analysis of beaches and the notion of temporality in French cinema [Fiona Handyside, The Cinema at the Shore: The Beach in French Film, (Berne: Peter Lang, 2014)].

5. Beeton, Travel, Tourism and the Moving Image, 16.

6. Beeton, Travel, Tourism and the Moving Image, 16.

7. Beeton, Travel, Tourism and the Moving Image, 5.

8. Beeton, Travel, Tourism and the Moving Image, 6-36.

9. Urry and Larsen, The tourist gaze 3.0, 1-30.

10. Urry and Larsen, The tourist gaze 3.0, 4.

11. Beeton, Travel, Tourism and the Moving Image, 15.

12. Ibid.

13. Ibid.

14. John Urry, The tourist gaze: leisure and travel in contemporary societies (London: Sage Publications, 1990).

15. Urry and Larsen, The tourist gaze 3.0, 1-30.

16. The film reviews were provided by the Bibliothèque du Film and requested through Cineressource.net (See Harrod, From France With Love: Gender and Identity in French Romantic 
Comedies [London: Bloomsbury], 2015: 12 for an overview of engaging with these film review sources).

I have also used a similar method of analysing film reviews for the purpose of critiquing political discourse and rhetoric in Lucas Belvaux's later film Chez Nous/ This is Our Land (2017) (See Steele, "Political Discourse and Rhetoric: Challenging twenty-first century populism in Chez Nous/ This is Our Land", The Routledge Companion to European Cinema, edited by Gabor Gergely and Susan Hayward, (London: Routledge, 2021), 437.)

17. Urry and Larsen, The tourist gaze 3.0, 28.

18. See Steele (2019) for a summary and overview of the film, Pas son genre. The analysis briefly outlines how Clément adopts an 'interstitial' position, travelling between Paris and Arras for the purposes of work. The primary point behind this short analysis in my previous work is to provide evidence for Belvaux as a filmmaker, who sets his films in a specific local context. Jamie Steele, Francophone Belgian Cinema (Edinburgh: Edinburgh University Press), 161.

19. Beeton, Travel, Tourism and the Moving Image, 15.

20. Beeton, Travel, Tourism and the Moving Image, 8-9.

21. Urry and Larsen, The tourist gaze 3.0, 4.

22. Beeton, Travel, Tourism and the Moving Image, 14; Urry and Larsen, The tourist gaze 3.0, 1.

23. Les Roberts, "Landscapes in the Frame: Exploring the Hinterlands of the British Procedural Drama", New Review of Film \& Television Studies, 14, no. 3: 371.

24. Beeton, Travel, Tourism and the Moving Image, 14.

25. James Williams, Space and Being in Contemporary French Cinema (Manchester: Manchester University Press, 2013), 8.

26. Michel de Certeau, "Walking in the City", In The Practice of Everyday Life" trans. Steven Rendall (Berkley: University of California Press, 1984), 98.

27. de Certeau, "Walking in the City", In The Practice of Everyday Life", 101.

28. de Certeau, cited in Willams, Space and Being in Contemporary French Cinema, 8.

29. A Youtube channel with a small number of subscribers (https://www.youtube.com/channel/ UCg6VDJ3spV8gkVZ_LcEM1fw/) includes three clips from Pas son genre. These clips articulate the place of Arras through its town squares, belfry and the carnival. They are curated alongside clips of other 'Northern' French films and TV programmes, such as Bienvenue chez les Ch'tis/ Welcome to the Sticks (Dany Boon, 2008), Quand la mer monte/ When the sea rises (Yolande Moreau and Gilles Porte, 2004), P'tit Quinquin/ Li'l Quinquin (Bruno Dumont, 2014) and Ma loute/ Slack Bay (Bruno Dumont, 2016). The act of online curation on Youtube highlights how they are continuities of icons, -such as the belfry, town squares, the beach, and carnivals - represented through French screen media.

Camille Goubert, Youtube, Accessed on August 31 2021. https://www.youtube.com/channel/ UCg6VDJ3spV8gkVZ_LcEM1fw/ .

30. Urry and Larsen, The tourist gaze 3.0, 1-30.

31. Urry and Larsen, The tourist gaze 3.0, 28.

32. Roger Riley, Dwayne Barker, and Carlton S. Van Doren, "Movie-Induced Tourism", Annals of Tourism Research, 25, no. 4, 1998, 924.

33. Urry and Larsen, The tourist gaze 3.0, 28.

34. Beeton, Travel, Tourism and the Moving Image, 15.

35. Roberts, "Landscapes in the Frame: Exploring the Hinterlands of the British Procedural Drama", 365-366.

36. Agat Films \& Cie and Artemis Productions, "Not My Type Dossier de Presse", Unifrance.org., 2013: 8.

37. In the Pas Son Genre Press Pack, the lead actress, Émilie Dequenne, also notes that Loïc Corbery (Clément in the film) would "sometimes" travel back and forth from Paris to Arras whilst 
shooting due to his commitments at the Comédie Française (See: Agat Films \& Cie and Artemis Productions, "Not My Type Dossier de Presse", Unifrance.org., 2013: 12).

38. The teaching profession in France is quite unique, since '[a] peculiar feature of the French education system is that teachers in the public sector are state civil servants and, as such, are recruited by a unique employer, the National Education Ministry'. (Guy Lapostolle and Thierry Chevaillier, "Teacher Training in France in the early 2010s", Journal of Education for Teaching, 37 (4), Taylor \& Francis: Routledge, 2011: 451.)

39. For a discussion of the postmodern traveller, see Marc Augé, Non-Place: Introduction to an anthropology of supermodernity (London; New York: Verso, 1995), 77-79, 101.

40. John Hopewell "Lucas Belvaux: 'The idea That Cinema is Also Art Protects Us a Bit", Variety, January 10, 2014.

41. Urry and Larsen, The tourist gaze 3.0, 24 .

42. For a brief discussion of music in the film, see Jordan Mintzler, "Not My Type (Pas son Genre): Film Review:, The Hollywood Reporter, April 23, 2014.

43. Jean-Pierre Blay, “"'Qu'est-qu'une nation”...Qui joue au football?”, Cahiers des Amériques latines 39, 2002, Online since August 6, 2017.

44. Hugh Dauncey and Geoff Hare, “'33 jours de fête”: A diary of France 98', Culture, Sport Society, 1:2: 1998, 200.

45. Nadine Hubbs, “'I will survive”: Musical Mappings of Queer Social Space in a Disco Anthem', Popular Music, 26: 2, May 2007: 231-244.

46. See the film reviews by Gallot, Kaganski, Sotinel, and Lorrain for references to 'class struggle', 'class structures' 'cultural and social differences' as articulated by the film's setting in Arras. Clémentine Gallot, 'Pas son Genre', Cahiers du Cinéma, No. 699, April 2014, 58; Serge Kaganski, 'Pas son genre de Lucas Belvaux', Les Inrockuptibles, April 30, 2014; Thomas Sotinel, 'L'amour est un champ de bataille', Le Monde, April 30, 2014; François-Guillame Lorrain, 'Dequenne, c'est notre genre!', Le Point, May 01, 2014.

47. Beeton, Travel, Tourism and the Moving Image, 13.

48. "Une desserte TGV est perçue comme une opportunité d'améliorer l'image, d'accroître l'attractivité et, dans certains cas, comme un outil permettant de développer l'activité touristique dans les VPM [villes petites et moyennes]"

Sylvie Bazin, Chrisophe Beckerick, and Marie Delaplace, "Desserte TGV et villes petites et moyennes. Une illustration par le cas du tourisme à Arras, Auray, Charleville-Mézières et Saverne", Les Cahiers scientifiques du transport, AFITL, no. 63, 2013, 38.

49. 'Cet effet étant plutôt un effet d'image selon le directeur de l'office de tourisme, et donc un effet indirect.'

(Sylvie Bazin, Chrisophe Beckerick, and Marie Delaplace "Desserte TGV et villes petites et moyennes. Une illustration par le cas du tourisme à Arras, Auray, Charleville-Mézières et Saverne", 48).

(See also : Sylvie Bazin, Chrisophe Beckerick, and Marie Delaplace "Desserte TGV et villes petites et moyennes. Une illustration par le cas du tourisme à Arras, Auray, Charleville-Mézières et Saverne", 50, 55.)

50. Thabourey notes the presence of the TGV in the film in his review. See: Vincent Thabourey, "Pas son genre", Positif, no. 639 (May 2014), 42.

51. Augé also outlines the role of high-speed rail in France. Augé, Non-Places: Introduction to an anthropology of supermodernity, 99.

52. See Augé for discussion of French town centres and place. Augé, Non-Places: Introduction to an anthropology of supermodernity, 64-65.

53. Fontaine, David. "Pas son genre: Arrageois de vivre", Le Canard Enchaîné, April 30, 2014.

54. Urry and Larsen, The tourist gaze 3.0, 28. 
55. Sylvie Bazin, Chrisophe Beckerick, and Marie Delaplace "Desserte TGV et villes petites et moyennes. Une illustration par le cas du tourisme à Arras, Auray, Charleville-Mézières et Saverne", 48.

56. 'Le spectateur se sent presque consolé d'avoir dû se tenir si longtemps en situation de voyeur, attendant que les pavés du Nord se dérobent sous les pas de la jolie fille amoureuse'. (Pascal Mérigeau, "L'amant de la coiffeuse", Le Nouvel Observateur, May 1, 2014).

57. Roger Riley, Dwayne Barker, and Carlton S. Van Doren, "Movie-Induced Tourism", Annals of Tourism Research, 25, no. 4, 1998, 924.

58. In the magazine Avant-Scène Cinema, Belvaux describes the setting of Arras as "décors presque de décors de théâtre". See Yves Alion and René Marx. "À l'occasion de la sortie de Pas son genre: Entretien avec Lucas Belvaux", Avant-Scène Cinema, no. 615, p. 126.

59. de Certeau, cited in Willams, Space and Being in Contemporary French Cinema, 8.

60. Urry and Larsen, The tourist gaze 3.0, 28.

61. Agat Films \& Cie and Artemis Productions, "Not My Type Dossier de Presse", 4.

62. Tim Bergfelder, Sue Harris, Sue., and Sarah Street. Film Architecture and the Transnational Imagination: Set Design in 1930s European Cinema, Amsterdam: Amsterdam University Press: 2007, 22.

63. According to the Press Kit, Pas son genre was shot in a 2.35 aspect ratio. This aspect ratio is generally 'associated with anamorphic Cinemascope, or multiple film, very wide display theatrical movies' (Faroudja, “Television system with variable aspect picture ratio”, United States Patent, 1988).

64. Bergfelder et al.. Film Architecture and the Transnational Imagination: Set Design in 1930s European Cinema, 22.

65. 'La scène sur la plage commence par un long travelling où ils ne se disent rien et puis, la discussion s'engage à la fois dans le temps et l'espace. Il faut les filmer où ils sont et rendre visible le temps qui passe' (Jean-Michel Vlaeminckx "Pas son genre de Lucas Belvaux", Cinergie, (May 1 2014)

66. Les Roberts, "Projecting Place: Location Mapping, Consumption, and Cinematographic Tourism". In The City and the Moving Image: Urban Projections, edited by Richard Koeck and Les Roberts (London: Palgrave, 2010), 193.

67. Locations France Film. "Presentation Sheet Berck-sur-Mer", Francefilm.net.

68. Roberts, "Projecting Place: Location Mapping, Consumption, and Cinematographic Tourism", 193.

69. Urry and Larsen, The tourist gaze 3.0, 28.

70. Urry and Larsen, The tourist gaze 3.0, 19.

71. See: Urry and Larsen, The tourist gaze 3.0, 19.

72. Urry and Larsen, The tourist gaze 3.0,19 - emphasis original.

73. Roberts, "Projecting Place: Location Mapping, Consumption, and Cinematographic Tourism", 193.

74. Locations France Film. "Village de Cassel", Francefilm.net.

75. Locations France Film. "Village de Cassel".

76. Urry and Larsen, The tourist gaze 3.0, 28.

77. “Au plus fou du carnaval qui imprime l'identité de cette région dont elle est fière, dont les poivrots l'amusent, clément ne saura se départir d'un regard d'anthropologue" (Dominique Widemann "Un film d'amour comme on parle d'une lettre d'amour", L'Humanité, (30 April 2014)).

78. Agat Films \& Cie and Aretmis Productions. "Not My Type Dossier de Presse", Unifrance.org, 2013:8.

79. 'Il tisse scènes poignantes, répliques qui font mouche et morceaux de satire légère du parisianisme ou du snobisme intellectuel' (David Fontaine "Pas Son Genre: Arrageois de vivre", Le Canard Enchaîné, April 30, 2014.). 
80. Urry and Larsen, The tourist gaze 3.0, 19.

81. "Pas son genre serait une comédie romantique [...] Lucas Belvaux consentait à décréter une trêve dans la guerre des classes" [Sotinel, "Pas son genre": l'amour est un champ de bataille", April 29, 2014.]

82. Beeton, Travel, Tourism and the Moving Image, 16.

83. Urry and Larsen, The tourist gaze 3.0, 19.

84. Urry and Larsen, The tourist gaze 3.0, 28.

85. Laurent-Sebastian Fournier, "Intangible Cultural Heritage in France: From State Culture to Local Development", In Heritage Regimes and the State, edited by Regina F. Bendix, Aditya Eggert, and Arnika Peselmann, Göttingen Studies in Cultural Property, Vol. 6 (Göttingen: Universitätverlag Göttingen), 335.

86. Laurent-Sebastian Fournier, "Intangible Cultural Heritage in France: From State Culture to Local Development", 335.

87. Timothy Baycroft Culture, Identity and Nationalism: French Flanders in the Nineteenth and Twentieth Centuries (London; Rochester, New York: Royal Historical Society), 39.

88. Baycroft Culture, Identity and Nationalism: French Flanders in the Nineteenth and Twentieth Centuries, 39).

Gueusquin also notes that 'reuze' translates into 'géants' [giants] from Flemish to French. See: Gueusquin, La ville et l'effigie: Emblématique et identités urbaines dans le Nord de la France au XXe siècle", 671.

89. 'Deux fois par an (l'homme à Mardi Gras, et le couple dans l'après-midi du Lundi de Pâques), leurs promenades rituelles célèbrent et concrétisent périodiquement un espace d'appartenance et de reconnaissance pour la population' (Marie-France Gueusquin, "La ville et l'effigie: Emblématique et identités urbaines dans le Nord de la France au XXe siècle”, Revue du Nord, 69, no. $274: 1987,671)$

90. 'Chacun participe, soit en collaborant directement au spectacle, soit en prenant part à la préparation des costumes, des vitrines mais aussi de la rue (déploiement des pavillons, flamands et nationaux, décoration des magasins et des maisons), soit encore par la remise d'un présent à l'un des mannequins' (Gueusquin, "La ville et l'effigie: Emblématique et identités urbaines dans le Nord de la France au XXe siècle", 672).

91. Laurent-Sebastian Fournier, "Intangible Cultural Heritage in France: From State Culture to Local Development", 336.

92. John Urry, The tourist gaze: leisure and travel in contemporary societies (London: Sage Publications, 1990).

93. I have also previously argued (for a sentence) that Belvaux uses the carnival sequence to draw attention to the 'cultural and regional differences' between Clément and Jennifer, which is in contrast to the representation of carnivals in Belgian cinema [Steele, Francophone Belgian Cinema, 99]. This article is differentiated through its close reading of the carnival sequence as a means of exploring an outsider's perspective on local traditions and customs in France, and how this perspective coheres with theoretical approaches to film tourism and Urry's concept of the "tourist's gaze".

94. Frédéric Strauss,"Pas son genre, Lucas Belvaux”, Télérama, (April 30, 2014).

95. 'Eux-mêmes prisonniers de ceux dont ils héritent à cause de leur métier, de leur statut social ou de leur façon d'aimer' (Strauss "'Pas son genre, Lucas Belvaux").

96. 'Lui le conçoit comme une prison et semble incapable de s'attacher' (Nathalie Simon "Émilie Dequenne, Féminin Plurielle", Le Figaroscope (April, 30 2014)).

97. Urry and Larsen, The tourist gaze 3.0, 29.

98. Nathalie Simon, "Émilie Dequenne, Féminin Plurielle".

99. de Certeau, "Walking in the City", In The Practice of Everyday Life, 101.

100. Urry and Larsen, The tourist gaze 3.0, 1-30. 


\section{ABSTRACTS}

This article argues that the re-presentation of space and place for global and local audiences constructs a touristic cultural imaginary. It highlights how - through the feature film Pas son genre/ Not my type (Lucas Belvaux, 2014) - the audience's gaze is centred on two cinematic spaces: the historical architecture of city centres and their local and cultural traditions and the 'icons' of global tourism, such as beaches. The article highlights how Urry's foundational concept of the "the tourist's gaze" ${ }^{1}$ is articulated through the movements of the characters, who organise the inter-relationships between cities, towns, and events. The analysis shows that it is precisely this romantic relationship between the characters and how they experience the region of Pas-deCalais, i.e. one as a local, and one as a visitor from Paris, that organises the snippets of the region and how they are experienced and interpreted by the spectator. The locations of Paris and, more importantly, Arras (and the region of Pas-de-Calais) offer layers of textual meaning that show the act of falling in love as aligned with the beach and the experience of the city, and a nostalgic yearning for tradition and customs present in small town contexts. The recognisable codes and icons of the Pas-de-Calais region are viewed by spectators through the lens of the characters and their immediate experiences that nuance the cinematic spaces.

\section{INDEX}

Keywords: screen tourism, icons, French cinema, cities, beaches, carnivals, leisure, holidaying

\section{AUTHOR}

\section{JAMIE STEELE}

Dr. Jamie Steele is Senior Lecturer in Film \& Screen Studies at Bath Spa University. In 2019, his first monograph, Francophone Belgian Cinema (Edinburgh University Press, 2019) was published as part of the Traditions in World Cinema series. He has also published book chapters for edited collections on Francois Ozon, political populism in French cinema, diasporic filmmaking in Belgium and filmmaking hubs and creative clusters, as well as journal articles on the Dardenne brothers' The Unknown Girl (2016) and the concept of the "transnational regional" in the context of French-language Belgian cinema. He was recently appointed Course Leader for the Undergraduate programme in Film and Screen Studies at Bath Spa University. 